\title{
COMPAIXÃO E POTENCIALIDADE INFINITAS: RESSIGNIFICANDO O CONCEITO DE “ONIPOTÊNCIA" DIVINA
}

\author{
Infinite Compassion and Potentiality: Resignifying the Concept of Divine \\ "Omnipotence"
}

Sinivaldo Silva Tavares *

RESUMO: Partindo do pressuposto de que o conceito de "onipotência" divina foi capturado pela Modernidade no intuito de fundamentar o domínio do sujeito pensante sobre tudo quanto existe, a intenção nossa é ressignificá-lo em diálogo com o teólogo franciscano Duns Scotus. Duas de suas proposições, entre outras, resultam particularmente relevantes no tocante ao objetivo que nos propomos: Deus como potencialização da liberdade e a univocidade do ente. "Compaixão e potencialidade infinitas" emergem, no bojo da ressignificação da onipotência divina, como traços distintivos do Criador. Destacamos, portanto, duas de suas dimensões características, promessa e cuidado, expressas por duas atitudes fundamentais no ato mesmo de criar: "atrair a partir de dentro" a história e a Criação à plenitude prometida e "deixar ser" como desejo de intimidade dialógica. Ao final, concluímos que o único poder que se autojustifica é aquele que eclode a partir de dentro porque gerado na fraqueza.

PALAVRAS-CHAVE: Modernidade. Scotus. Onipotência divina. Compaixão. Potencialidade.

ABSTRACT: Based on the assumption that Modernity has captured the concept of divine "omnipotence" in order to justify the thinking subject's dominion over all things created, our intention is to resignify it through a dialogue with the Franciscan theologian Duns Scotus. Two of his proposals, among others, are particularly relevant to our aim: God as promoter of freedom and the univocity of the being. "Infinite compassion and potentiality" emerge, in the midst of the resignification of

* Faculdade Jesuíta de Filosofia e Teologia, Belo Horizonte, Minas Gerais, Brasil. 
divine omnipotence, as distinctive features of the Creator. We therefore emphasize two of its characteristic dimensions, promise and care, expressed by two fundamental attitudes in the very act of creating: "attracting from within" the history and creation for attaining the promised fullness and "letting it be" as a desire for dialogic intimacy. As a conclusion, we found that the only self-justified power is that which springs from within, as it is generated in weakness.

KEYWORDS: Modernity. Scotus. Divine omnipotence. Compassion. Potentiality.

\section{Introdução: ressignificar o conceito de "onipotência" divina}

$\mathrm{R}$ econhecemos que possa parecer ousada nossa pretensão: ressignificar o conceito de "onipotência" divina. O abuso do poder que, de forma escandalosa, vem caracterizando nossas democracias representativas tem tornado o poder cada vez mais um tema tabu. Seria, de fato, o poder privilégio de alguns e estaria condenado a se exercer de forma autoritária e abusiva? Ou, ao contrário, seria o poder uma dimensão intrínseca a cada pessoa humana, segundo as expressivas palavras de $\mathrm{H}$. Arendt: "Então não posso fazer isso? Posso. Sou livre." (ARENDT, 1993, p. 212)? Pois, afinal, etimologicamente a palavra "poder" não nos remeteria à ideia de "potencialidade", no grego e no latim e também nas línguas modernas? Deflagramos, de início, um processo de "captura" do conceito de onipotência divina, inaugurado pela Modernidade, com um interesse bem preciso: colocar Deus como fundamento, não deixando nada infundado, para tornar robusto e consistente o domínio do sujeito pensante sobre tudo quanto existe. Num segundo momento, elegemos o filósofo e teólogo franciscano Duns Scotus para nos conduzir nesse labirinto excogitado pela Modernidade. Filho daquele período descrito por Huizinga como "outono da Idade Média", Scotus é apresentado por alguns como precursor, em certo sentido, da Modernidade. Graças a posições filosóficas e teológicas muito próprias, Scotus se revela, simultânea e paradoxalmente, moderno e anti-moderno. Ao defender o pluralismo epistemológico, ele constitui um dos primeiros rebentos daquele processo histórico que desembocou na Modernidade. Todavia, enquanto concretização de uma "epistemologia forte", racionalista e naturalista, a Modernidade nasce e se desenvolve num viés oposto àquele inaugurado e proposto por Scotus (TODISCO, 1996, p. 85-93). Ao final, delineamos traços da imagem do Criador que emerge a partir da ressignificação de sua onipotência: "compaixão e potencialidade infinitas". Destacamos, portanto, duas de suas dimensões características, promessa e cuidado, expressas por duas atitudes fundamentais no ato

\footnotetext{
${ }^{1}$ Inclusive na língua alemã, onde Macht vem de mögen e möglich (possível), embora aparentemente pareça vir de machen (fazer).
} 
mesmo de criar: "atrair a partir de dentro" a história e a Criação à plenitude prometida e "deixar ser" como desejo de intimidade dialógica. Pois, afinal, o único poder que se autojustifica é aquele que eclode a partir de dentro porque gerado na fraqueza.

\section{0 advento da Modernidade e a "captura" da onipotência divina}

Com o advento da Modernidade, no intuito de fundamentar a estabilidade do cosmos e o caráter veritativo das proposições do sujeito pensante, a providência divina passa a ser interpretada como "racionalidade". Entenda-se racionalidade, aqui, em um duplo sentido: fundamento racional de tudo quanto existe e garantia da índole não enganadora das faculdades cognitivas do sujeito moderno. Na Modernidade, portanto, providência e racionalidade se identificam como realidades objetivas e vinculantes. Num tal contexto, o Deus da fé cristã foi concebido preferentemente como onipotente, vale dizer, todo-poderoso. Imagens do Criador como "relojoeiro", "arquiteto" ou até mesmo de "designer" surgem nesse preciso horizonte epocal.

\subsection{Fundamento racional e garantia de verdade cognitiva do sujeito pensante}

Para não sucumbir face ao "arbítrio despótico", a vontade de Deus teria necessariamente que se submeter a um princípio eterno e imutável? E o pressuposto não seria uma ilusão do próprio sujeito moderno: imaginar um deus submisso a verdades eternas e imutáveis às quais também ele viria a se submeter? Não se verificaria, em tal caso, a pretensão de limitar o próprio Deus impondo-lhe peias em sua ação Criadora? Não deixar nada infundado, subtraindo as criaturas de sua precariedade, para reforçar e afirmar o domínio do sujeito pensante sobre tudo quanto existe: eis o intento do projeto moderno. Pondo Deus como fundamento, a trama racional do sujeito moderno se torna mais robusta e consistente.

Talvez resulte claro por quais motivos a parábola do Ocidente tenha-se dado historicamente como um caso de identificação com a busca da verdade: caráter epistêmico (gregos), verdade teológica (medievais), caráter transcendental (modernos) ou técnico-científico (contemporâneos). Como também talvez se compreenda melhor por qual razão a verdade tenha sido pensada pela racionalidade ocidental em termos de adequação entre a proposição e a coisa (veritas est adaequatio intellectus et res). E não teria sido justamente esse o motivo - o fato de ter sido concebida como conformidade - pelo qual a verdade tenha sido reduzida a mero objeto à mercê do sujeito pensante e, portanto, sua propriedade? Talvez essa seja 
a principal razão pela qual a verdade tenha sido quase sempre imposta de maneira intolerante e, portanto, excludente em relação ao outro de si. De fato, o não verdadeiro, nesta configuração precisa, é tido sem mais como falso. Dado o seu caráter incontestável, a verdade assim concebida expulsa toda não-verdade, interpretada como falsidade. O entendimento só é concebido no âmbito da verdade e, em seu interior, predominam o contraste, a competição e a desconfiança. Entendida, sobretudo, como expressão da consciência pensante, a verdade se torna motivo de orgulho e não de gratidão, vindo a se converter, consequentemente, em fonte de direitos e de reinvindicações em benefício próprio, gerando, por sua vez, situações de contrastes ideológicos, de fundamentalismos e de toda sorte de violência. A verdade assim concebida dá segurança porque, em última instância, confere poder ${ }^{2}$. O Ocidente, enquanto terra da razão, tem se revelado como a terra do poder dominação. Segundo o aforisma de F. Bacon, "conhecer é poder" (nosse est posse). Nesse sentido, o triunfo da tecnociência constitui o natural epílogo da aventura ocidental como terra do domínio, sonho esse perseguido tenazmente desde o seu nascedouro. Não por acaso, ocidente vem de occidens, que significa: ocaso, morte.

\subsection{O Criador como "relojoeiro", "arquiteto", "Intelligent Designer"}

Constatamos que boa parte das teologias acabou engolindo a isca que lhes foi lançada pela Modernidade. Razão pela qual, o Criador foi concebido como o princípio, a origem de todas as coisas. Só que, origem passou a ser entendida como fundamento estático a fornecer as melhores garantias para que o projeto do ser humano moderno, concebido como sujeito pensante, pudesse ser levado a termo de forma voluptuosa e desimpedida. Foi nesse contexto que se aplicou ao Criador a imagem do "relojoeiro". O estudioso da técnica Lewis Munford, em seu sugestivo livro Technics and Civilization, discorre sobre a fascinante história de um aparelho simples, porém emblemático: o relógio (MUNFORD, 1994). Mais do que a locomotiva, ou a máquina a vapor, talvez essa máquina do tempo seja a que melhor represente o capitalismo industrial e, por extensão, a Modernidade. De fato, a Modernidade forjou a imagem de um mundo mecânico, no

\footnotetext{
${ }^{2}$ Etimologicamente, o termo veritas se constrói sobre a raiz indo-européia ver, cujo significado é abrigo, refúgio e remédio face à experiência da admiração e do assombro diante do insensato, do inapreensível, do ingovernável. Como superar essa angústia mortal? O pensamento ocidental nasce assediando a contingência, experimentada como âmbito do casual, do imprevisível e do inédito. Dominando-a mediante a verdade, pondo-se ao reparo e remediando o caráter de assombro da realidade. Ao se exprimir através da universalidade e da necessidade, a racionalidade ocidental se dilata, expandindo seus tentáculos sobre o real, agarrando-o de maneira voluptuosa. Este intento que se faz presente na aurora da filosofia encontra na tecnociência sua expressão mais plena (TODISCO, 2008, p. 138-143).
} 
seio do qual também o ser humano passou a ser interpretado como uma máquina. Se se considera o relógio como metáfora do mundo e do ser humano nele situado, talvez se entenda melhor por qual motivo Leibniz, ao excogitar a imagem do Deus cristão como responsável e garante de toda a engrenagem moderna, o tenha concebido mediante a plástica metáfora do relojoeiro. Outras imagens do Criador difundidas no horizonte da cultura moderna, dentre as quais se destacam a da "mente de Deus", empregada por Stephen Hawking, e a do "designer" proposta pelos fautores do "Intelligent Design", têm por função principal instrumentalizar o Criador, concebendo-o como o fundamento e a certeza do projeto ideado e realizado pelo sujeito moderno.

Os adeptos do "Intelligent Design", por exemplo, julgam ter provas científicas das contínuas intervenções de Deus, por eles considerado o "Intelligent Designer", que explicariam os saltos e as incongruências perceptíveis na irredutível complexidade da natureza (DEMSKI, 1999; BEHE, 1996). Defendem, portanto, uma concepção intervencionista do Criador, considerado "projetista", que, situando-se fora da Criação, interviria em alguns de seus momentos cruciais para garantir a harmonia e a estabilidade das criaturas e seus inerentes processos. Neste sentido, estas imagens traem, no fundo, uma concepção do Criador como um intervencionista e, portanto, alheio e indiferente face ao mundo. Por se encontrar fora da realidade, em determinados momentos críticos, Ele se intrometeria na trama da vida da qual ele não participa ordinariamente. Tais intervenções trairiam um poder arbitrário e coercitivo do Criador, posto que comprometeriam a autonomia das realidades criadas. Por fim, o grande limite dessas imagens modernas do Criador e da Criação é concebê-los como realidades que se dão no assim chamado reino da necessidade. Elas resultam necessárias no intuito de fundamentar e sustentar o projeto do ser humano moderno. Tudo parece circunscrito a um script predeterminado ou preestabelecido. Por alguma razão, as coisas tinham que existir e tinham que existir do jeito que são.

Resulta clara, assim, a parábola da Modernidade que, ao relegar o Criador a fundamento estático e indiferente à sorte e ao destino de suas criaturas, acabou selando a absoluta separação entre Criador e criaturas. As mutações ocorridas na própria concepção do Criador resultam lineares e espontâneas: de um deus entendido como fundamento estático passa-se às imagens de um deus tapa-buracos, intervencionista até atingir seu cume nas expressões modernas do ateísmo. O palco da Modernidade acabou ensejando o espetáculo por vezes patético, outras vezes trágico, da luta renhida entre dois sujeitos, onipotentes e autônomos, que não se suportam reciprocamente. As várias vertentes do ateísmo dos séculos XIX e XX comungam de um mesmo pressuposto: Deus e ser humano se encontram em uma situação de contínua competição; para que um se afirme, é necessário que o outro se anule. 


\section{Amor e possibilidade infinitos: a "onipotência" divina segundo Scotus}

Salientamos a peculiaridade de Scotus no exercício mesmo de seu pensamento: servindo-se de análise minuciosa e rigorosa, busca compreender cada termo em íntima e recíproca relação com seu correlato, desentranhando uma série de binômios, onde cada termo se torna compreensível à luz do outro e vice-versa. Suas análises, portanto, se efetuam mediante pares de termos recíprocos e mutuamente inclusivos. Este rigoroso processo de semantização é acompanhado por uma série de distinções sutis. Ele não se perde, todavia, no emaranhado das distinções; ao contrário, ao desentranhar as sutis dimensões, mais nitidamente emergem as intrínsecas articulações (GHISALBERTI, 1995, p. 276s). Operando uma autêntica desconstrução do primado do intelecto sobre a vontade, da liberdade sobre a necessidade e da caridade sobre a verdade, Scotus põe como nó central de sua trama o par de termos recíprocos e complementares: liberdade e contingência (TAVARES, 2008, p. 772-806). O primado universal de Cristo é, em última instância, o núcleo mais íntimo dos primados que Scotus propõe: da vontade sobre o intelecto, da caridade sobre a verdade, da liberdade sobre a necessidade, do singular sobre o universal, da pessoa humana sobre a espécie. Todavia, este primado escotiano não deve ser entendido como a substituição do primeiro termo do binômio pelo segundo. Ele não separa nem contrapõe os polos; a partir da afirmação de um polo ele inclui o outro como seu recíproco. Não se trata, por exemplo, de uma vontade arbitrária nem despótica. A vontade não se opõe, nem nega o intelecto, mas o transcende. A mesma coisa vale com relação à liberdade. Ela não é a-racional nem arbitrária. Ela transcende a necessidade, revelando-se como seu horizonte de sentido.

Do pensamento rico e complexo de Scotus, queremos aqui destacar duas de suas posições que nos parecem relevantes no que tange à ressignificação da onipotência divina: a afirmação de Deus como pura possibilidade e, de consequência, o caráter positivo do contingente; a discutida questão da univocidade do ente (TODISCO, 2003; 2006; 2008).

\subsection{Deus como potencialização da liberdade e o caráter positivo do contingente}

Para Scotus, tudo é possível para Deus, exceto aquilo que constitui uma "manifesta contradição", ou seja, o que não é possível em si (Reportata Parisiensia, IV, d. 10, q, 3, n. 13). Embora distinga em Deus duas potências: uma absoluta - através da qual pode agir como quer - e outra ordenada - graças à qual age segundo uma ordem - , Scotus sustenta que ambas são reais e que tudo depende em modo absoluto do Criador. A própria ordem obedece à disposição divina, não sendo, portanto autônoma. As leis 
e normas correspondentes à ordem são, portanto, garantia de liberdade. Neste sentido, recuperar a liberdade se torna condição de possibilidade do caráter provisório e reformável de qualquer universo normativo. A índole própria do Criador, portanto, é a potencialização da liberdade criativa. Scotus afirma que a liberdade é a natureza mais própria de Deus e que, por isso, é a liberdade que eleva o ser humano até o Criador.

Com base nas reflexões até aqui conduzidas, emerge a questão do princípio de não contradição, pérola da lógica e ontologia gregas. Para Tomás de Aquino, aquilo que repugna à mente humana - que algo seja e não seja ao mesmo tempo e o que não aconteceu tenha acontecido - não pode não aparecer estranho à mente divina. Ele chega a afirmar que "não cai sob a onipotência divina aquilo que implica contradição" (Summa Theologiae, I, q, 25, a. 4, resp.). No artigo $6^{\circ}$ da questão 25, o Aquinate se pergunta se Deus podia fazer as coisas de outro modo: melhor e mais perfeito. E sua resposta é que Deus teria podido melhorar o mundo em seus detalhes, não, porém, na sua substância (Summa Theologiae, I, q. 25, a. 6, ad 1). Portanto, Deus não teria podido fazer um mundo mais perfeito do que este (Summa Theologiae, I, q. 25, a. 6, ad 3). O Criador teria podido não fazer o que fez. O que significa que ele não se sente obrigado a fazer o que fez. Mas, querendo fazer, não podia fazer senão o que fez. Trata-se de um conjunto de princípios eternos que Deus não pode transgredir. Scotus, ao contrário, reduz a amplitude do princípio da não contradição ao afirmar contundentemente a liberdade como traço distintivo de Deus. Em primeiro lugar, convém tomar consciência do que Deus quer e, somente depois, proceder à exploração racional de sua vontade. Qualquer princípio tem vigência apenas e enquanto dentro de um sistema pré-estabelecido. Por esta razão, não é possível evocar qualquer princípio para traçar o percurso que Deus não teria podido percorrer. Não existem regras acima de Deus, fonte primordial de toda e qualquer verdade e, portanto, de leis e de princípios. Excluindo, portanto, toda norma ou princípio que diga respeito à ação criativa de Deus, o discurso de Scotus se transfere para o volitum que se furta a todo e qualquer processo de racionalidade rígida. Em tal caso, a referência passa a ser ao que é possível que seja e não propriamente ao que é. Pois, afinal, as contradições devem ser eliminadas ou acolhidas com tal? Não seria o caso de se propor um modelo alternativo de racionalidade? Pois, afinal, um Deus limitado pelo princípio da não contradição seria, ainda, Deus? Na perspectiva cristã, Deus é onipotente e, justamente enquanto tal, Ele pode fazer tudo o que quer, como e quando quer, compreendido, segundo Scotus, "theologice" (Ordinatio, I, d. 42, q. u., n. 9). Scotus é taxativo ao afirmar que não estamos à altura de conhecer Deus "in particulari et proprie". Não estamos em condições de conhecer o Criador na sua singularidade absoluta (Ordinatio, I, d. 3, p. 1, qq. 1-2, n. 56). Isso pressuposto, como dizer o que Deus pode e o que não pode fazer, em nome de princípios de nossa mente? Recuperando, portanto, a fecun- 
didade da liberdade, Scotus salvaguarda a historicidade e a relatividade de nosso conhecimento. A questão da "manifesta contradição" se refere à ausência das mínimas condições do possível. É o que Scotus chama de "impossibile simpliciter", por exemplo, que a pedra possa se tornar sábia.

Após este breve excursus sobre o princípio de não contradição, passemos a considerar o que Scotus diz acerca da origem dos possíveis. Ele lembra que os gregos tematizavam o "possível" no interior do binômio: potência-ato. Em tal caso, não se dá assimetria entre o real e o possível, uma vez que ambos pertencem ao ser desde sempre e para sempre. São coexistentes reciprocamente graças a uma necessidade interna. Ao afirmar a contingência radical das criaturas, Scotus salienta a centralidade do não-ser, expressão do inédito e, portanto, condição mesma de possibilidade de tudo o que vem à existência. Deste modo, entre mundo existente e mundo possível vigora uma relação de reciprocidade posto que o primeiro não se dá sem o segundo. Ao querer o mundo existente, quer-se também remissivamente o mundo possível. Não se dá existente que não se abra ao possível, tanto no tocante ao que ainda não é quanto ao que com ele não é possível no quadro da ordem atual. A consequência deste pressuposto é a superação da lógica ambivalente. Não se dão apenas o verdadeiro e o falso, o bem e o mal, o positivo e o negativo. Também se dão o não-verdadeiro-nem-falso, o não-bem-nem-mal. Trata-se da área do neutro e do indiferente onde se situa o agente livre, que, além de escolher um dos pólos do dilema, pode fazer seu o terceiro valor e ali habitar. É o espaço da sua preguiça ou da sua criatividade.

Uma visão coisificada (objetivista) do real impede que se descortinem as eventuais brechas possíveis, reais ainda que não existentes. Esta perspectiva interpela-nos a assumir uma atitude distinta, alternativa: enriquecer o real mediante todas as possíveis alternativas em consonância com a dinâmica própria da onipotência. O único vínculo é a "manifesta contradição" sobre a qual falamos acima. O problema, neste caso, não é a impotência do agente, mas a impossibilidade da ação devida à ausência das condições objetivas de sua produção (Ordinatio, I, d. 43, n. 19). É radical a posição de Scotus: tudo o que não é Deus é contingente e é positivo. Não apenas Deus, portanto, mas também o que não é Deus é positivo. Para ele, o contingente não deve ser concebido negativamente como precário ou caduco. Ele não é mero efeito de uma necessidade intrínseca ou natural. Fato evidente e constatável e, portanto, não passível de demonstração nem "a priori" nem "a posteriori", o contingente é, todavia, extremamente significativo. Enquanto volitum, ele é portador de sentido. Trata-se de uma intuição não mediada nem mediável (Ordinatio, I, d. 39, q. u., a. 3, n. 13). Na perspectiva grega, o contingente constitui um defeito, é expressão daquilo que não é, mas que pode vir a ser, destinado, antes ou depois, a existir. Na ótica escotiana, como já tivemos ocasião de sublinhar, o contingente constitui um modo de ser positivo e intrínseco de ser: se é, é porque Alguém quis 
que ele fosse (Ordinatio, I, d. 39, q. u., a. 5, n. 35). O contingente não existe por si; se assim o fosse, não seria contingente, mas necessário; e, no caso em que não o seja, não se pode dele dizer privado de algo do qual tivesse direito. Embora venha do nada - pois antes não era e agora é - o contingente não re-envia ao nada como dirá mais tarde Sartre. O contingente, de fato, é sem porquê, mas nem por isso, sem sentido. Justamente por se furtar a todo tipo de explicação é que o contingente constitui interpelação à busca pelo seu sentido. Por não ser fruto de um sistema fechado que segue rigidamente o ritmo causa-efeito, o contingente se apresenta como aberto, retificável e, portanto, passível a todo tipo de mudança. Por isso, cada identidade é contingente e, enquanto tal, modificável, retificável, flexível e aberta à diferença. $\mathrm{O}$ contingente, por isso mesmo, re-envia ao possível. Só o possível pode se converter em expressão de liberdade. A consciência do contingente, enquanto algo jamais compreendido exaustivamente, estimula-nos, na condição de fonte abissal, a acolher sempre as ressonâncias do mistério.

Encontramo-nos, assim, no âmago da experiência cristã: o mundo é aquilo que Deus quis e a história, aquilo que nós humanos queremos. Sob a ótica do primado da vontade, Deus e ser humano estão fora de toda e qualquer prisão, revelando-se não como meros expectadores, mas como autênticos atores. Neste caso, o que mais torna o ser humano semelhante a Deus é a liberdade e não o intelecto. Como entender, afinal, a liberdade? Não seria ela aquele fundo abissal do nosso ser no interior do qual as escolhas se maturam em meio às circunstâncias nas quais nos encontramos? Não seria ela expressão de nossa índole auto-transcendente que nos capacita a criar ou destruir, ampliar os espaços da existência ou fechá-los? Não seria ela a medida de nossa capacidade de se autoafirmar, tornando possível outras formas de liberdade? Ousaríamos dizer que a dignidade humana se encontra mediante a potencialização de sua liberdade.

\subsection{A univocidade do ente}

A conhecida tese escotiana da univocidade do ente permite que se fale de Deus não apenas analogicamente, mas em termos positivos ou unívocos ${ }^{3}$. A teoria da univocidade protege a liberdade de Deus, pois ao sustentar o caráter positivo do contingente, Scotus afirma a índole radicalmente possível das criaturas. Elas não são efeitos necessários como uma espécie de emanação proveniente de uma única fonte. Enquanto contingentes, as criaturas estão intimamente referidas à condição de possibilidade de sua própria existência.

\footnotetext{
${ }^{3}$ Esta tese de Scotus tem se tornado novamente objeto de crítica por expoentes da "Ortodoxia Radical" dentre os quais se destaca o teólogo anglicano John Milbank. Ele alega que a "univocidade do ente" teria feito deslanchar um processo de mudança paradigmática em âmbito teológico que, por sua vez, estaria nas origens da Modernidade e suas distintas vertentes de secularização (HORAN, 2014).
} 
Isso significa que, antes de vir a ser, as criaturas eram pura possibilidade (GHISALBERTI, 1999, p. 5-18). O contingente é algo que poderia não ser no momento mesmo em que veio a ser, ou no exato momento em que passou a existir. Com a afirmação da univocidade, Scotus situa a contingência para além da analogia e da composição dos entes. Ele pretende, mediante sua análise, voltar à origem do ente a partir do nada de seu ser. Os modos fundamentais do ser, finito e infinito, são ambos positivos, inclusive suas ramificações ontológicas. Na perspectiva grega, o contingente constitui uma degradação do ser. Na ótica cristã, ele é expressão de perfeição porque, em última instância, alude ao que não era e agora é, não porque devia ser mas porque Alguém quis que fosse. O contingente não é apenas o que poderia não ser, mas também aquilo cujo oposto poderia ser no exato momento em que se dá (Ordinatio, I, d. 2, p. 1, qq. 1-2, n. 86).

A univocidade do ente sublinha a total dependência de tudo o que existe Àquele que o chama à existência e, portanto, salienta a radical transcendência de Deus que poderia não querer o que quer no momento exato no qual o quer. Neste sentido, o Criador se revela na sua absoluta alteridade em relação às criaturas. Não é que Scotus inclua em uma única e mesma dinâmica o finito e o infinito. Ele os distingue nitidamente. No entanto, sua noção de ente parece ser o caminho mais eficaz para salvaguardar a abertura do ser humano ao ser infinito e, ao mesmo tempo, a absoluta transcendência de Deus em relação a tudo o que é finito. Neste sentido, a univocidade do ente cria as condições para que se compreenda como e por qual motivo o finito possa ser acolhido como símbolo do infinito. Daí a índole simbólico-sacramental do finito na sua intrínseca relação com o infinito. Assim, Scotus postula que a diferença entre Deus e nós não deve ser colocada no fato que Ele é e nós não somos, mas no distinto modo de ser: enquanto Deus goza de um modo infinito de ser, nós somos na modalidade de finitos. A ontologia do ente enquanto ente, nota característica do pensamento de Scotus, só se ocupa de Deus enquanto ente infinito; distinta, portanto, da outra perspectiva, de caráter nitidamente teológico: aquela que considera Deus ut haec essentia, que é o objeto específico da teologia enquanto tal. Assim como o singular o é com respeito ao universal, a compreensão de Deus como ente infinito não deve ser negada, ao contrário, superada. É graças à revelação que Scotus alcança a afirmação de que Deus é causa voluntária e livre (Quaestiones super Metaphysicam, q. 1, n. 11). Para Scotus, portanto, "Deus vult quia vult": a vontade divina é suprema. Deus não se sente vinculado ou condicionado a nada nem a ninguém. Quis o que quis mesmo podendo não o querer ou ainda querê-lo diversamente: este mundo e não outro, estas criaturas e não outras são um dom, porque, em última instância, queridas pelo Criador.

Nesta nova configuração, emerge a relação dialética entre total dependência e autonomia plena das criaturas em relação ao Criador. Neste sentido, Scotus toma distância das doutrinas emanacionistas bem como dos modelos 
incriados que postulam a participação das criaturas com respeito ao Criador. Scotus fala de instantes distintos, mediante os quais, primeiro Deus ama e conhece a si mesmo e só depois ama e conhece suas criaturas. $\mathrm{O}$ ser humano, de fato, embora tenha sido criado livre, se descobre sempre no interior de um sistema do qual se sente responsável e também artífice, embora não o tenha criado. Deus, sim, Ele é Criador de sistemas e jamais seu prisioneiro. Porque cria do nada, Deus pode tudo. Sua liberdade é sem limites. Para Scotus, nada é absoluto fora da liberdade. A parábola da condição humana revela sua índole paradoxal: ao dirigir seu olhar para o finito, o ser humano se descobre perdido no infinito. E tal consciência permite que dilate seus próprios horizontes, sem, contudo, perder de vista a tão necessária concretude de sua existência. Concebida como transcendência ou independência com relação às coisas, a liberdade se revela como o traço divino no ser humano e, portanto, seu núcleo ontológico mais consistente. $\mathrm{O}$ mundo resulta assim como a alteridade mais absoluta com relação a Deus, seu Criador. Ele se encontra, de fato, suspenso ao tênue fio da vontade livre de Deus e à mercê de sua potência criativa. Respiração divina no coração do tempo, o mundo, a rigor, não é nem divino, nem profano: mas dom querido e sustentado pela gratuidade amorosa do Criador.

\section{3 "Compaixão e potencialidade infinitas": o autêntico sentido de onipotência}

Fomos, no decorrer da Modernidade, demasiadamente habituados a conceber Deus como o fundamento estático de todas as coisas, circunscrevendo-o quase exclusivamente ao passado. Consequentemente, o passado passou a ser considerado como determinante do presente e do futuro. Construímos grandes sistemas nos quais não apenas o presente resultava condicionado inelutavelmente pelo passado, mas também o futuro passou a ser concebido como algo programado e, portanto, absolutamente previsto. Deste modo, o futuro acabou destituído de toda e qualquer ulterioridade. Hoje, sobretudo a partir dos estudos da Física Quântica e da Neurociência, aprendemos que necessário se faz recuperar a prioridade do futuro sobre o passado na concepção do tempo e a prioridade da potencialidade sobre o real no conceito de realidade. Pois, na verdade, é o futuro que acorda as potencialidades adormecidas do passado e não o contrário. Da mesma forma, cada realidade se revela apenas como uma entre tantas possíveis realizações, embora essa concretização seja irreversível. Só assim poderemos compreender, de fato, o devir como o princípio que estrutura a inteira realidade tornando-a um autêntico sistema aberto, vale dizer, num contínuo processo incompleto porque em vias de completude. Neste horizonte de compreensão, Deus não se revelaria como a fonte de onde promanam todas as possibilidades e, ao mesmo tempo, como a origem de todo o 
tempo a partir da dinamicidade própria do futuro? Ao invés, portanto, de insistirmos em interpretar o Deus bíblico como a determinação de todo o real, não seria talvez o caso de concebê-lo como a "possibilização máxima do possível" (MOLTMANN, 2007)? Ou ainda, segundo Haught, como "fundamento infinitamente generoso de novas possibilidades para o vir-a-ser do mundo" (HAUGHT, 2006, p. 146)?

\subsection{A Criação como "promessa": "presença libertadora" como garantia da plenificação futura}

Há algumas décadas, Carlos Mesters já nos punha diante de pergunta crucial: "Paraíso terrestre: saudade ou esperança" (MESTERS, 1971). De fato, fomos habituados a interpretar os relatos bíblicos das origens como uma espécie de descrição do início cronológico de tudo quanto existe. Imersos nessa experiência avassaladora do tempo como kronos, descuidamos de outras experiências do tempo como a do kairós, por exemplo, no interior do qual "origem" é o princípio de irrupção de toda e qualquer realidade e que, enquanto tal, não se situa estaticamente no início cronológico de sua existência, mas em sua própria raiz, a destilar aquela seiva vivificante.

O povo bíblico é particularmente sensível à vida experimentada como evento. Daí sua preocupação com a história e o caráter inusitado de seus acontecimentos. O nó central da trama bíblica é a experiência da Aliança. Os processos cósmicos não lhe passam despercebidos, são acolhidos e experimentados em íntima relação com a historicidade da vida. Neste sentido, percebe-se nas narrativas bíblicas da Criação uma estreita relação entre as experiências de libertação/salvação e Criação. No transfundo de tais narrativas, emerge uma coerente profissão de fé: Aquele que, no presente, se revela como "presença libertadora" e que acompanha a caminhada de seu povo na direção de um futuro bom e reconciliador, é o mesmo que se revela na origem como Criador de tudo quanto existe.

A fé no Deus Criador ressurgiu justamente nos momentos mais críticos da história do povo bíblico; momentos em que sua fé nas promessas divinas e sua esperança no futuro encontravam-se ameaçadas pela dureza e crueldade do presente. E a fé no Criador lhe servia de estímulo a recuperar a confiança na presença e interpelação de Deus no seu presente, abrindo perspectivas na direção do futuro. É nesse preciso contexto que ecoam as palavras de Isaías: "Não vos lembreis das coisas passadas, nem considereis as antigas. Eis que faço uma coisa nova! Já está despontando: porventura não o percebeis?" (Is 43,18-19a). Portanto, a fé bíblica no Criador comporta uma tríplice dimensão de Criação: 1) a Criação como evento que se dá no momento presente (cf. o texto do profeta Isaías, citado acima); 2) a Criação como plenitude da obra divina: "Eis que faço novas todas as coisas" (Ap 21,5); 3) a Criação no princípio: “No princípio criou Deus o céu e a terra" (Gn 1,1). 
Não há, portanto, na tradição de fé do povo bíblico, nenhum ranço de separação, menos ainda de contraposição, entre os eventos da Criação, da história da salvação e dos tempos definitivos. Eles distinguem a história da origem primordial do tempo e da plenitude de todo o tempo. Todavia não as separam nem as contrapõem. Na sua distinção, o tempo escandido na sua tríplice dimensão (passado, presente e futuro) se encontra habitado pelo Deus bíblico que se revela como presença libertadora. Esta específica experiência de fé encontra-se na origem da construção de ricas e sugestivas metáforas no interior dos relatos bíblicos da Criação. Segundo os relatos bíblicos da Criação que se encontram em Gn 1 e 2, é o Criador quem cria seja pela habilidade e genialidade de suas mãos seja pela força e eficácia de sua Palavra. Em ambos os casos, o cuidado do Criador é explicitado como fonte e origem de tudo quanto existe. Em ambos os relatos, mediante metáforas, transparece a presença simultânea de dois elementos constitutivos da fé bíblica: 1) a origem divina do mundo: 2) a autonomia do mundo e a liberdade de suas criaturas. Esta consciência se encontra na raiz da profissão de fé no Deus Criador: a experiência da gratuidade da vida.

A concepção da Criação como gratuidade transparece de maneira mais clara ainda em $\operatorname{Pr} 8$, 22-31, no qual a obra da Criação é explicitamente associada à experiência lúdica. A singularidade deste relato é a figura da sabedoria, metaforicamente, descrita como uma criança que, durante todo o tempo, brinca na presença do Criador, divertindo-se e entusiasmando-se dia após dia com o conjunto de suas criaturas (EUVÈ, 2006, p. 132-142). Esta metáfora da Criação como um jogo talvez seja a mais adequada para reassumir toda a riqueza de detalhes da fé bíblica na Criação como experiência de gratuidade porque, no fundo, fruto do desejo livre e gratuito de um Deus que é, ao mesmo tempo, Criador e Pai.

A mover a inteira história bíblica da salvação são as promessas divinas em vias de realização. É a partir do futuro que o Criador atrai a história na direção de um final bom e reconciliador. "E Deus viu que tudo era bom" é uma exclamação que retorna após cada dia da Criação, segundo o relato de Gn 1. Esta espécie de refrão constitui contínua interpelação à confiança na destinação boa e plenificadora do universo. Esta exclamação continua ressoando por entre os meandros sutis da inteira Criação, como uma promessa divina. E promessa nos remete à missão. De fato, promessa vem de pro-missio. E, por isso, ela propicia o emergir da missão concebida como incumbência: empenho pela radical transformação deste mundo para que ele se torne, lenta e teimosamente, plenamente bom. Deus criou-nos como interlocutores seus, justamente por querer colaboradores na tarefa de tornar esse mundo plenamente bom. E esta tarefa é nossa em comunhão com o Criador. Os textos bíblicos são claros na concepção do fim dos tempos não como tempos derradeiros, mas como a plenitude de todo o tempo. Neste sentido o paraíso narrado na Bíblia não deve ser considerado como algo perdido em um passado distante. Fato que, entre outras coisas, 
poderia provocar situações obsessivas de expiação e vitimização castradoras. Imaginar o paraíso como passado perdido acabaria tornando-nos reféns de nostalgia inercial e doentia. Conceber o paraíso como futuro prometido, ao contrário, propicia o despertar de nossas melhores energias no intuito de antecipar, no aqui e agora, as promessas do Criador.

\subsection{Criar é "deixar ser": "não presença" como intimidade dialógica}

O Criador se abstém de toda e qualquer presença "forte" que possa resultar em "presença anuladora" da autonomia das criaturas e, de modo especial, da liberdade do ser humano. Por essa razão, se abstém de dirigir ou controlar a trama da Criação, ou mesmo de absorvê-la em si. O Criador, na verdade, se contrai, em uma espécie de "não presença" para que suas criaturas sejam e se façam presentes em sua legítima autonomia. E essa contração não significa desinteresse ou indiferença face à vida e ao destino de suas criaturas. Ao contrário, essa sua "não presença" se torna condição mesma de possibilidade daquela intimidade dialógica que o Criador instaura com cada uma e com todas elas. E a pedagogia do Criador é a sedução e não a coerção ou intimidação. Movido por compaixão, vale dizer, por seu amor criativo, Ele cria o mundo como ontologicamente distinto de si. Por isso a Criação é fruto da decisão divina e não mera extensão ou apêndice de sua divindade.

Expressão privilegiada do que estamos dizendo é a consciência tão bem expressa na clássica profissão de fé na "Criação do nada". Duas são as perspectivas a partir das quais conceber a "Criação do nada": a do Criador e a de suas criaturas (TAVARES, 2010, p. 80-83). Na ótica do Criador, o criar a partir "do nada" é, rigorosamente falando, criar a partir de si mesmo. Por ser o único Deus, sua presença é plena. Não existe, a rigor, coisa qualquer que se possa considerar "fora de Deus". Em sua onipotência infinita, Deus se revela também como onipresente. Todavia, para criar "do nada", Deus constitui o nada, não como algo fora dele, mas, como um espaço autônomo, ainda que dentro dele. E esta constituição do nada, como primeiro e imprescindível passo para a Criação de todas as criaturas, se dá mediante uma retração quenótica do Criador. É como se o Criador se retirasse, reservando assim um espaço para suas criaturas autônomas, apesar de continuar a envolve-as por todos os lados. Talvez a metáfora do útero materno possa tornar mais clara esta concepção do criar "do nada". A geração do filho implica no fato de a mãe lhe reservar um espaço no interior do qual seu rebento possa se desenvolver. Não que o útero constitua um espaço separado do corpo da mãe. Ele demarca um espaço reservado para o crescimento do feto, apesar de se encontrar física e organicamente no interior do corpo da mãe. De forma análoga, o Criador se retrai para dar lugar às suas criaturas, respeitando-lhes a autonomia. Mas isto não significa que o Criador se desinteresse por elas ou que lhes 
seja indiferente. Ao contrário, continua envolvendo-as por todos os lados com sua terna presença, não obstante as respeite em sua sadia autonomia e soberana liberdade. Em outras palavras, criar "do nada" significa respeitar as criaturas na sua irredutível diferença. Criar "do nada" implica em pôr diante de si o diferente e, portanto, constitui-lo como seu interlocutor na trama histórico-salvífica, cujo desfecho querido é o encontro e a comunhão do Criador com suas criaturas.

Concebida a partir do ser humano, esta Criação "do nada" constitui a condição mesma de possibilidade de sua liberdade. Fomos queridos livres para que pudéssemos amar. Pois o amor pressupõe decisão livre e espontânea. Não se pode constranger alguém ao amor. $\mathrm{O}$ amor pressupõe liberdade. Ademais, porque criado e querido "do nada", o ser humano é livre até para se considerar, para todos os efeitos, causa de si próprio, negando em tudo e por tudo sua umbilical relação com o Criador. Por outro lado, o ser humano também pode sucumbir à tentação de exercitar sua liberdade, porém, negando-a, preferindo viver como eterno dependente do Criador, incapaz de empenhar a própria liberdade no exercício de sadia autonomia. Neste sentido, o ser humano vive como se estivesse na corda bamba, dividido entre o considerar-se dependente e o rebelar-se contra seu Criador, vivendo como emancipado e isolando-se, portanto, do Criador e das demais criaturas. Assumir a própria existência na mais genuína autenticidade significa aceitar sua condição primordial de criatura querida por Deus como "ser do nada". O ser humano não constitui uma mera continuação ou extensão de seu Criador. A relação que existe entre Criador e criatura não se resume a uma continuidade pura e simples ou a algo que se dê de forma natural e espontânea. A relação entre Deus e nós é fruto de uma decisão livre, por parte de ambos, que se dá mediante relações de reciprocidade. Não fomos criados para permanecer em dependência paralisante e castradora, comprometendo assim nossa singularidade. Deus nos quer e nos trata como adultos. Quer que nos empenhemos de maneira lúcida e consciente na tarefa de corresponder a seus apelos. Quer que nossa resposta seja livre e madura, expressão da vontade sincera de corresponder a seu amor gratuito. Quer, em suma, que nossa resposta também seja expressão de amor.

Neste sentido, Deus não se encontra apenas na origem de nossa existência, como uma espécie de primeiro movente, sujeito de um impulso primordial, que, depois de ter dado origem a todo e qualquer movimento, permanece distante e indiferente à nossa sorte e ao nosso destino. Mas, ao contrário, por respeitar nossa autonomia e liberdade, Ele se coloca do nosso lado, dispondo-se a percorrer conosco, lado a lado, os caminhos difíceis da história, como nosso companheiro, interlocutor privilegiado. Mais ainda, Deus nos envolve por todos os lados e vem habitar no mais íntimo de nós, sem, contudo, violentar minimamente nossa autonomia e liberdade. Deus se nos revela como futuro em aberto, atraindo a história e o cosmos todo, desde dentro, para um final bom e plenificador. Este final 
dos tempos concebido não apenas como tempos derradeiros, mas como a plenitude de todo o tempo, culminará na transfiguração não apenas da existência de cada uma e de todas as criaturas, mas na transfiguração total e completa do inteiro cosmos, potencializando e explicitando ao máximo suas íntimas relações. Assim concebido, "o nada" a partir do qual Deus cria se revela como lugar de uma insólita e inusitada fecundidade. $\mathrm{O}$ nada não se confunde com a total ausência. Ele é, em última instância, a possibilidade máxima da existência de todas as coisas. Compreendida escatologicamente, a "Criação do nada" implica na máxima potencialização do "nada" por desejo gratuito do Criador para que as criaturas convirjam, lenta e teimosamente, para o encontro último e definitivo na plenitude dos tempos. Em outras palavras, sem faltar com o respeito para com a autonomia de suas criaturas, o Criador as predispõe a celebrar com ele um encontro de comunhão como cumprimento de todo o tempo.

\section{Conclusão: a "in-habitação" do Espírito como "creatio continua"}

Dizíamos, na introdução, que o único poder que, afinal, se autojustifica é aquele que eclode a partir de dentro porque gerado na fraqueza. Dá o que pensar, neste sentido, a afirmação do teólogo e mártir da resistência ao Nazismo, Bonhöffer: "Deus é impotente e fraco no mundo, e exatamente assim, Ele está conosco e nos ajuda". Palavras que continuam a ressoar em nosso século na afirmação do filósofo italiano Gianni Vattimo: "Só um Deus fraco pode nos salvar agora". De fato, a onipotência do Criador só poderá ser concebida a partir da autêntica experiência de kénosis (esvaziamento, despojamento) que se revela mediante um tríplice movimento: retração do Pai que, como vimos, ao nos chamar à existência, cria-nos "do nada"; despojamento do Filho que nos salva, resgatando-nos, mediante seu gesto de extrema solidariedade, "do nada do pecado"; e, ainda, in-habitação (escondimento) do Espírito Santo que continua realizando com lento vagar sua obra de santificação mediante a plenificação das pessoas, da história e do cosmos inteiro (TAVARES, 2007, p. 192-210).

Esta "Criação contínua" vem se dando no Espírito que in-habita no tecido íntimo da natureza, nos sulcos da história e no âmago mais recôndito do ser humano e de cada criatura, para, a partir daí, iniciar sua lenta obra de plenificação de cada criatura e da inteira Criação. Esse seu modo interior e silencioso de operar revela que toda autêntica transformação vem sempre de dentro para fora. A singularidade do Espírito Santo se revela sobremaneira nesta sua peculiar maneira de se fazer presente e de agir interna e intimamente. Ele vem habitar no interior de cada uma de suas criaturas, no tecido da história e nos meandros sutis do cosmos 
para potencializar no melhor dos modos as singularidades e alteridades que compõem as relações interpessoais, a trama da história e a complexa teia das criaturas todas. Mediante o seu Espírito, Deus se revela como a interioridade mais íntima de cada criatura e, portanto, da complexidade da Criação. Vindo a habitar na interioridade de cada criatura, o Espírito provoca o desabrochar da singularidade mais própria dela; inserindo-se no coração da humanidade, Ele a fermenta desde o seu interior; e, finalmente, permeando o seio do cosmos, Ele potencializa ao máximo a riqueza e a pluralidade da Criação propiciando a unidade profunda na comunhão. $\mathrm{O}$ Espírito, ademais, não opera massificando. Seu modo peculiar de ser na alteridade mais radical de cada criatura, faz com que possam emergir as mais distintas singularidades potencializando-as ao encontro e à comunhão. Trata-se, em definitiva, de um processo de autêntico escondimento do Espírito Santo. Escondimento que provoca o emergir das distintas singularidades. Escondimento que salienta as intrínsecas relações de reciprocidade entre as distintas singularidades. Escondimento que, enfim, cria as condições para a realização daquele desígnio primordial divino: celebrar com suas criaturas o encontro e a comunhão.

\section{Referências}

ARENDT, H. A condição humana. Rio de Janeiro: Forense Universitária, 1993.

BEHE, M. Darwin's Black Box: The Biochemical Challenge to Evolution. New York: The Free Press, 1998.

DEMSKI, W. Intelligent Design: the Bridge Between Science \& Theology. Illinois: InterVersity Press, 1999.

EUVÈ, F. Pensar a Criação como jogo. São Paulo: Paulinas, 2006.

GHISALBERTI, A. Metodologia del sapere teologico nel Prologo alla 'Ordinatio' di Giovanni Duns Scoto. In: SILEO, L. (a cura di). Via Scoti. Methologica ad mentem Joannis Duns Scoti. Atti del Congresso Scotistico Intenazionale, Roma 9-11 marzo 1993, v. I, p. 276-277, Roma 1995.

J. Duns Scot et la théologie rationelle d'Aristote. Reoue des Sciences Philosophiques et Théologiques, Paris, v. 83, n. 1, p. 5-18, janvier, 1999.

HAUGHT, J.-F. Deus após Darwin: uma teologia evolucionista. Rio de Janeiro: José Olympio, 2000.

HORAN, D. Postmodernity and Univocity: a Critical Account of Radical Orthodoxy and John Duns Scotus. Minneapolis: Fortress Press, 2014.

MESTERS, C. Paraíso terrestre: saudade ou esperança? Petrópolis: Vozes 1971.

MOLTMANN, J. Ciência e Sabedoria: um diálogo entre ciência natural e teologia. São Paulo: Loyola, 2007.

MUNFORD, L. Técnica y civilización. Madrid: Alianza Editorial, 1994. 
SCOTUS. Reportata Parisiensia. In: Opera Omnia. Paris: Ludovicum Vivès, 18931894. v. 22-24.

v. $1-14$.

Ordinatio. In: Opena Omnia. Roma: Typis Plyglottis Vaticanae, 1950-2013.

- Quaestiones super Metaphysicam: Questions on the Metaphysics of Aristotle. Book X. Int. e com. Allan B. Wolter. New York: The Franciscan Institute, 2000.

TAVARES, S.S. Trindade e Criação. Petrópolis: Vozes, 2007.

. A Criação na perspectiva ecológica: a contribuição de Scotus, Revista Eclesiástica Brasileira, Petrópolis, v. 68, n. 272, out., p. 772-806, 2008.

. Teologia da Criação. Outro olhar - novas relações. Petrópolis: Vozes, 2010.

TODISCO, O. “Duns Scoto e il pluralismo epistemológico". In: SILEO, L. (a cura di), Via scoti. Methologica ad mentem Joannis Duns Scoti. Atti del Congresso Scotistico Intenazionale, Roma 9-11 marzo 1993, v. I, Roma 1995.

TODISCO, O. "Scoto tra medioevo e modernità". In: IDEM, Giovanni Duns Scoto. Filosofo della liberta, Edizioni Messaggero de S. Antonio, Padova 1996. p. 85-93.

. Lo stupore della ragione. Il pensare franciscano e la filosofia moderna. Padova: Messaggero Padova, 2003.

. Il dono dell'essere. Sentieri inesplorati del Medioevo franciscano. Padova: Messaggero Padova, 2006.

. La libertà fondamento della verità. Ermeneutica franciscana del pensare occidentale. Padova: Messaggero Padova, 2008.

TOMÁS DE AQUINO. Suma Teológica. Parte III. Questões 1-59: O mistério da Encarnação. São Paulo: Loyola, 2002.

Artigo submetido em 15.06.2018 e aprovado em 05.11.2018.

Sinivaldo S. Tavares é frade franciscano e doutor em Teologia Sistemática pela Pontificia Università Antonianum, Roma. Desde 2012 é professor de Teologia sistemática e pesquisador no Programa de pós-Graduação em Teologia da Faculdade Jesuíta de Filosofia e Teologia (FAJE), Belo Horizonte. Orcid.org/0000-0002-3617-9116. E-mail: freisinivaldo@gmail.com

Endereço: Av. Dr. Cristiano Guimarães, 2127 - Planalto 31.720-300 - Belo Horizonte - MG 